\title{
Comparison of reproductive performance in lactating dairy cows bred by natural service or timed artificial insemination
}

\author{
F. S. Lima, ${ }^{*}$ C. A. Risco, ${ }^{\star 1}$ M. J. Thatcher, ${ }^{*}$ M. E. Benzaquen, ${ }^{*}$ L. F. Archbald, ${ }^{*}$ J. E. P. Santos, $\dagger$ \\ and W. W. Thatchert \\ *Department of Large Animal Clinical Sciences, College of Veterinary Medicine, and \\ †Department of Animal Sciences, University of Florida, Gainesville 32611
}

\begin{abstract}
The objective of this study was to compare reproductive performance of lactating dairy cows bred by natural service (NS) or timed AI (TAI). One thousand fifty-five cows were blocked by parity and enrolled to receive either NS or TAI. Cows in both groups were presynchronized with 2 injections of $\mathrm{PGF}_{2 \alpha}$ given at 42 and $56 \mathrm{~d}$ postpartum. Fourteen days after the last $\mathrm{PGF}_{2 \alpha}$ injection, cows in the TAI group were enrolled in an Ovsynch protocol (d $0 \mathrm{GnRH} ; 7 \mathrm{~d}$ later, $\mathrm{PGF}_{2 \alpha}$; $56 \mathrm{~h}$ after $\mathrm{PGF}_{2 \alpha}$ injection, second dose of $\mathrm{GnRH}$; and $16 \mathrm{~h}$ after second GnRH cows were TAI). Cows in the TAI group were resynchronized with an intravaginal insert containing progesterone inserted $18 \mathrm{~d}$ after TAI and removed $7 \mathrm{~d}$ later when GnRH was given. Cows were examined by ultrasonography on d 32 after TAI; nonpregnant cows received $\mathrm{PGF}_{2 \alpha}$ and $\mathrm{GnRH} 56 \mathrm{~h}$ later followed by TAI $16 \mathrm{~h}$ after the GnRH injection. Nonpregnant cows in TAI group were reinseminated up to 5 times using the same scheme. Cows in the NS group were exposed to bulls $14 \mathrm{~d}$ after the second $\mathrm{PGF}_{2 \alpha}$ injection, and ultrasonography was performed $42 \mathrm{~d}$ after exposure to bulls to determine pregnancy status. Nonpregnant cows in the NS group were reexamined by transrectal palpation combined with ultrasound every $28 \mathrm{~d}$ until diagnosed pregnant or $223 \mathrm{~d}$ postpartum, whichever occurred first. Cows diagnosed pregnant in TAI or NS were reconfirmed $28 \mathrm{~d}$ later to determine pregnancy loss. All bulls underwent an evaluation of breeding soundness and were rested for $14 \mathrm{~d}$ after $14 \mathrm{~d}$ of cow exposure. Health disorders were evaluated up to $70 \mathrm{~d}$ postpartum, and body condition score was evaluated at d 70 postpartum. Blood was collected on d 56 and 65 postpartum and analyzed for progesterone to determine cyclicity. The proportion of pregnant cows in the first $21 \mathrm{~d}$ of breeding did not differ between groups. The overall 21-d cycle pregnancy rate (PR),
\end{abstract}

Received March 9, 2009.

Accepted August 11, 2009.

${ }^{1}$ Corresponding author: riscoc@vetmed.ufl.edu which included a total of 8 and 5 service opportunities for NS and TAI, respectively, was not different between groups (25.7 and $25.0 \%$ for NS and TAI, respectively). The daily rate of pregnancy was $15 \%$ greater for NS than TAI because cows in NS had a greater PR, which resulted in fewer median days open (111 vs. 116 d). Proportion of pregnant cows at $223 \mathrm{~d}$ postpartum was greater in the NS than TAI group (84.2 vs. $74.8 \%$, respectively). Cyclicity did not affect reproductive performance. Cows with body condition score $\geq 2.75$ had greater proportion of pregnant cows in the first $21 \mathrm{~d}$ of breeding and daily $\mathrm{PR}$ in the first $223 \mathrm{~d}$ postpartum Primiparous cows had greater proportion of pregnant cows and daily PR than multiparous cows at $223 \mathrm{~d}$ postpartum. In conclusion, the greater proportion of pregnant cows in the NS group was attributed to more opportunities for breeding than in the TAI group.

Key words: timed artificial insemination, natural service, reproductive performance, dairy cow

\section{INTRODUCTION}

Despite considerable advantages for AI, a significant number of dairy producers use natural service (NS) for their breeding program. In a survey on bull management practices in California, $84 \%$ of the producers reported use of NS as a component of their breeding program (Champagne et al., 2002). The most common use of NS was after unsuccessful AI attempts. In dairy herds located in the northeast region of the United States, reported use of NS as a component of the breeding system varied from 55 to $74 \%$ (NAHMS, 2002; Smith et al., 2004). In a study that compared pregnancy rates (PR) between AI and NS in Georgia and Florida dairy herds, the use of NS alone or in combination with AI was reported to be around $70 \%$ (de Vries et al., 2005). A survey that examined management practices in 103 herds participating in the Alta Genetics (Watertown, WI) Advantage Progeny Testing Program reported that $43 \%$ of herds used a clean-up bull (Caraviello et al., 2006). Nonpregnant cows were moved to the cleanup pen after 6 unsuccessful AI or 232 d postpartum. A 
common perception among dairy producers is that NS is comparable to AI because human errors in estrous detection are avoided with bulls.

Several studies have compared reproductive performance between AI and NS breeding systems. Pregnancy rates obtained from dairy herd records of cows bred by AI or NS were not different (Williamson et al.,1978; Niles et al., 2002), but PR from NS were more variable in NS herds (deVries et al., 2005). Using DHIA herd summary information, actual calving interval was shorter in herds that used NS bulls (Smith et al., 2004). The effects of AI and NS breeding systems on PR by stage of lactation and season over an 8-yr time period showed that the use of NS bulls did not result in meaningful advantages or disadvantages in terms of PR over time (deVries et al., 2005). In contrast to the previously cited reports, a California study that compared calving to conception intervals for cows in AI pens with cows exposed to NS sires found that cows AI had a higher risk for pregnancy across all days in milk cohorts (Overton and Sischo, 2005).

A breeding program that synchronizes ovulation and AI at a fixed time (timed AI; TAI) has been developed that allows for $100 \%$ of the cows to be submitted to AI, without the need for estrous detection (Pursley et al., 1995). Ample studies have clearly demonstrated an advantage in PR of TAI over insemination at detected estrus (Pursley et al., 1997a, b; Cartmill et al., 2001). However, studies that compare reproductive performance between NS and TAI, 2 breeding systems in which efficiency of estrous detection is not a factor, are lacking. It was hypothesized that the use of TAI would result in a greater 21-d cycle PR than NS because in TAI cows undergo ovulation synchronization, and all eligible cows are inseminated at a fixed time. Therefore, the objective of this study was to compare reproductive performance of lactating dairy cows bred by TAI or NS, 2 breeding system in which estrous detection is not required.

\section{MATERIALS AND METHODS}

\section{Animals, Housing, and Diets}

The University of Florida Institutional Animal Care and Use Committee approved all procedures involving cows and bulls. The study was conducted between November 2006 and March 2008 in a commercial dairy farm of 2,200 Holstein cows located in north central Florida. Cows were housed in free-stall barns with fans and sprinklers for forced evaporative cooling during the warm season. Four barns (2 TAI; 2 NS), each with a maximum capacity of 180 cows, were used in the study. These barns were similar in design, size, and number of animals housed and were switched between and within seasons to avoid environmental bias. Resting bulls were housed in bermudagrass pasture lots with portable shades and trees for heat abatement. Lactating cow diets were formulated using the CPM-Dairy cattle ration analyzer (version 3.0.7a, Cornell University, Ithaca, NY; University of Pennsylvania, Kennett Square, PA; and William H. Miner Agricultural Research Institute, Chazy, NY) to meet or exceed the nutrient requirements established by NRC (2001) for lactating Holstein cows weighing $650 \mathrm{~kg}$, consuming $24 \mathrm{~kg} / \mathrm{d}$ of DM, and producing $45 \mathrm{~kg} / \mathrm{d}$ of milk containing $3.5 \%$ fat and $3.1 \%$ true protein during the first $80 \mathrm{~d}$ of lactation. The composition of the diets consisted of corn silage, alfalfa hay, ground corn, citrus pulp, cottonseed hulls, expeller soybean meal (SoyPlus, West Central Soy, Ralston, IA), and solvent-extracted soybean meal. Bulls were fed the lactating cow diet during the 2 -wk cow exposure period and lactating cow diet weigh back, which averaged 17.2 $\mathrm{kg} / \mathrm{d}$ of DM per bull, during the 2-wk rest period.

\section{Study Design, Treatments, and Exclusion Criteria}

Once a week until completion of the study, lactating Holstein dairy cows were blocked by parity (primiparous and multiparous) and randomly allocated within each block at $42 \pm 3 \mathrm{~d}$ postpartum into 2 groups, TAI $(\mathrm{n}=543)$ and NS $(\mathrm{n}=512)$. Before study enrollment, cows underwent a reproductive tract examination and health record evaluation. Cows with uterine infection or adhesion, a displaced abomasum, cesarean section, or fetotomy, and cows that missed any part of their experimental protocol were not included in the study. After enrollment, cows that were sold or died or missed any part of their protocol were removed from the study. Accordingly, 89 cows from the TAI group and 118 cows from NS cows were removed.

\section{TAI Reproductive Management}

Cows in the TAI group were presynchronized with 2 injections of $\mathrm{PGF}_{2 \alpha}$ (500 $\mu \mathrm{g}$ of cloprostenol sodium, Estroplan; Pfizer Animal Health, New York, NY) given at $42 \pm 3$ and $56 \pm 3 \mathrm{~d}$ postpartum. Fourteen days after the second injection of $\mathrm{PGF}_{2 \alpha}$ cows were given an injection of GnRH (100 $\mu \mathrm{g}$ of gonadorelin, Fertagyl; Intervet Inc., Millsboro, DE) followed $7 \mathrm{~d}$ later by an injection of $\mathrm{PGF}_{2 \alpha}$, and a second injection of $\mathrm{GnRH} 56$ $\mathrm{h}$ after the last dose of $\mathrm{PGF}_{2 \alpha}$. The TAI was performed $16 \mathrm{~h}$ after the second injection of GnRH. Eighteen days after TAI, cows received a controlled internal drug-releasing insert (CIDR; CIDR Eazi-Breed; Pfizer Animal Health) followed by insert removal and $\mathrm{GnRH}$ administration $7 \mathrm{~d}$ later on d 25 after TAI. Cows were 

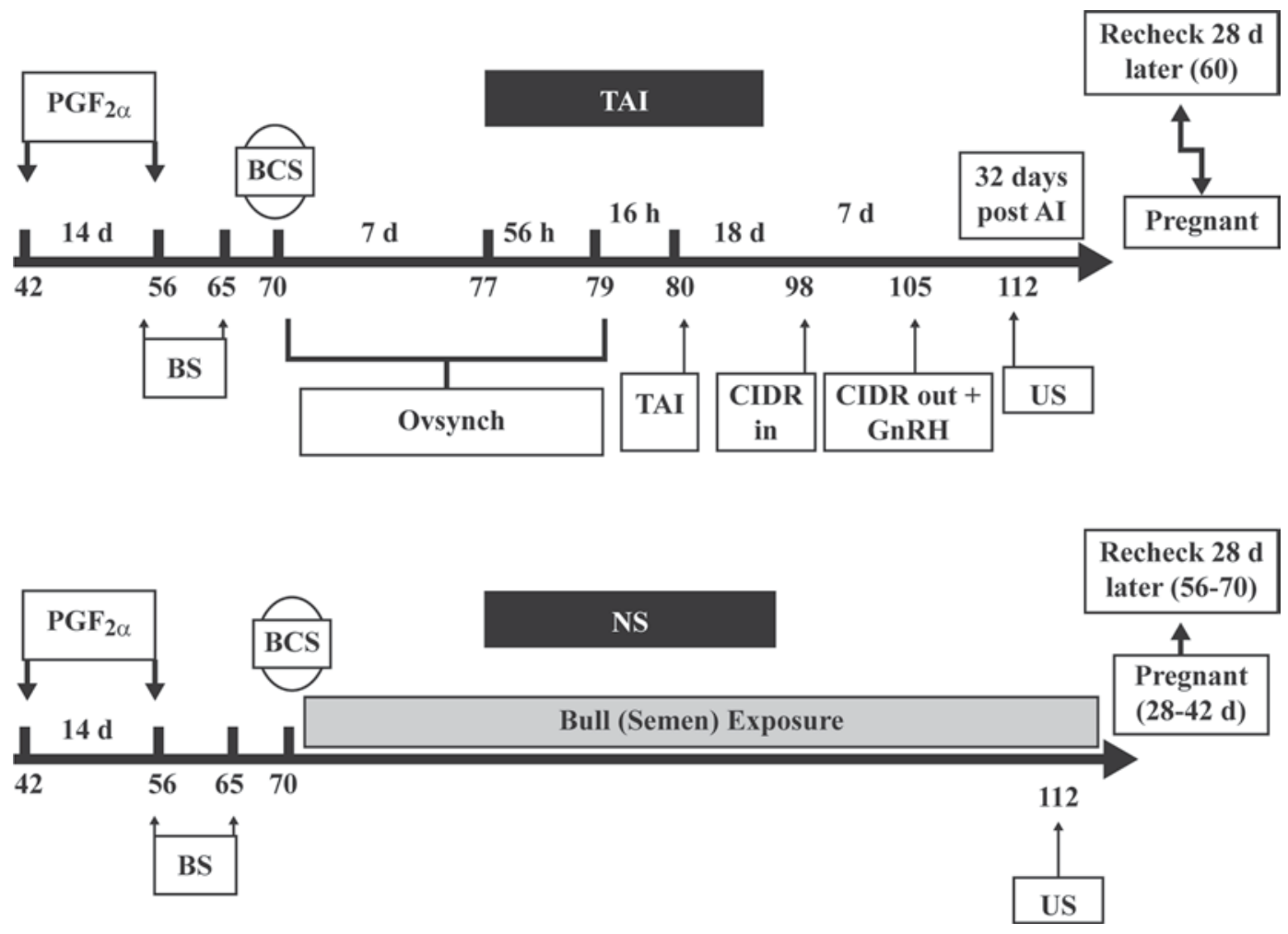

Figure 1. Timeline of reproductive events to the first service, blood sample collection, and body score evaluation for cows enrolled at timed $\mathrm{AI}$ (TAI) and natural service (NS) breeding programs. BS = blood sample; US = ultrasonography examination; CIDR = controlled internal drug-releasing insert.

evaluated for pregnancy by ultrasonography examination at $32 \mathrm{~d}$ after TAI. The reproductive program for TAI cows is illustrated in Figures 1 and 2. The presence of an embryo with a heartbeat was the criterion used to determine pregnancy as described previously (Ginther, 1998). The resynchronization protocol was chosen to maximize reproductive efficiency and to allow cows to be reinseminated immediately after the diagnosis of nonpregnancy. Based on ovarian dynamics at $18 \mathrm{~d}$ after $\mathrm{AI}$, a preovulatory follicle is potentially present, and insertion of a CIDR device will maintain this follicle and not allow ovulation in cows with a regressed corpus luteum. When GnRH is administered $7 \mathrm{~d}$ later at CIDR insert removal (d 25 after insemination in TAI cows), ovulation of the follicle is expected and a new follicular wave is initiated. Therefore, cows found nonpregnant at $32 \mathrm{~d}$ after $\mathrm{AI}$ would be ready to receive $\mathrm{PGF}_{2 \alpha}$ and complete the modified Ovsynch protocol at $35 \mathrm{~d}$ from their previous breeding. In this manner, the modified Ovsynch protocol begins $7 \mathrm{~d}$ before the diagnosis of nonpregnancy, which shortens the interval between inseminations.

Cows diagnosed pregnant were reexamined by transrectal palpation of the uterus and its contents $28 \mathrm{~d}$ later (i.e., $60 \mathrm{~d}$ gestation) to reconfirm pregnancy sta- tus and to identify pregnancy loss. Cows diagnosed not pregnant at $32 \mathrm{~d}$ after TAI were administered $\mathrm{PGF}_{2 \alpha}$, followed with an injection of $\mathrm{GnRH}$ at $56 \mathrm{~h}$ after $\mathrm{PGF}_{2 \alpha}$, and TAI was performed $16 \mathrm{~h}$ after GnRH. Nonpregnant cows were resynchronized again with the same TAI protocol until diagnosed pregnant or at a maximum of 223 d postpartum.

\section{NS Reproductive Management}

Cows in the NS group received $\mathrm{PGF}_{2 \alpha}$ at $\mathrm{d} 42 \pm 3$ and $56 \pm 3$ and were moved to a bull pen at $70 \pm 3$ d postpartum. Cows were moved to the bull pen $14 \mathrm{~d}$ after the last $\mathrm{PGF}_{2 \alpha}(70 \pm 3 \mathrm{~d}$ postpartum $)$ to improve synchronized estrus and to have the bull breeding at around $80 \mathrm{~d}$ postpartum, i.e., similar to the first service in the TAI group. After $42 \mathrm{~d}$ of being exposed to the bulls, cows underwent an ultrasonography and transrectal examination to determine pregnancy status, which allowed a diagnosable gestation length in pregnant cows to vary from 28 to $42 \mathrm{~d}$. The reproductive program for NS cows is illustrated at Figures 1 and 2. Gestation age was estimated by measurement of embryo size, presence of a heartbeat by ultrasound (Ginther, 1998), and the diameter of the pregnant uterine horn and length of the 

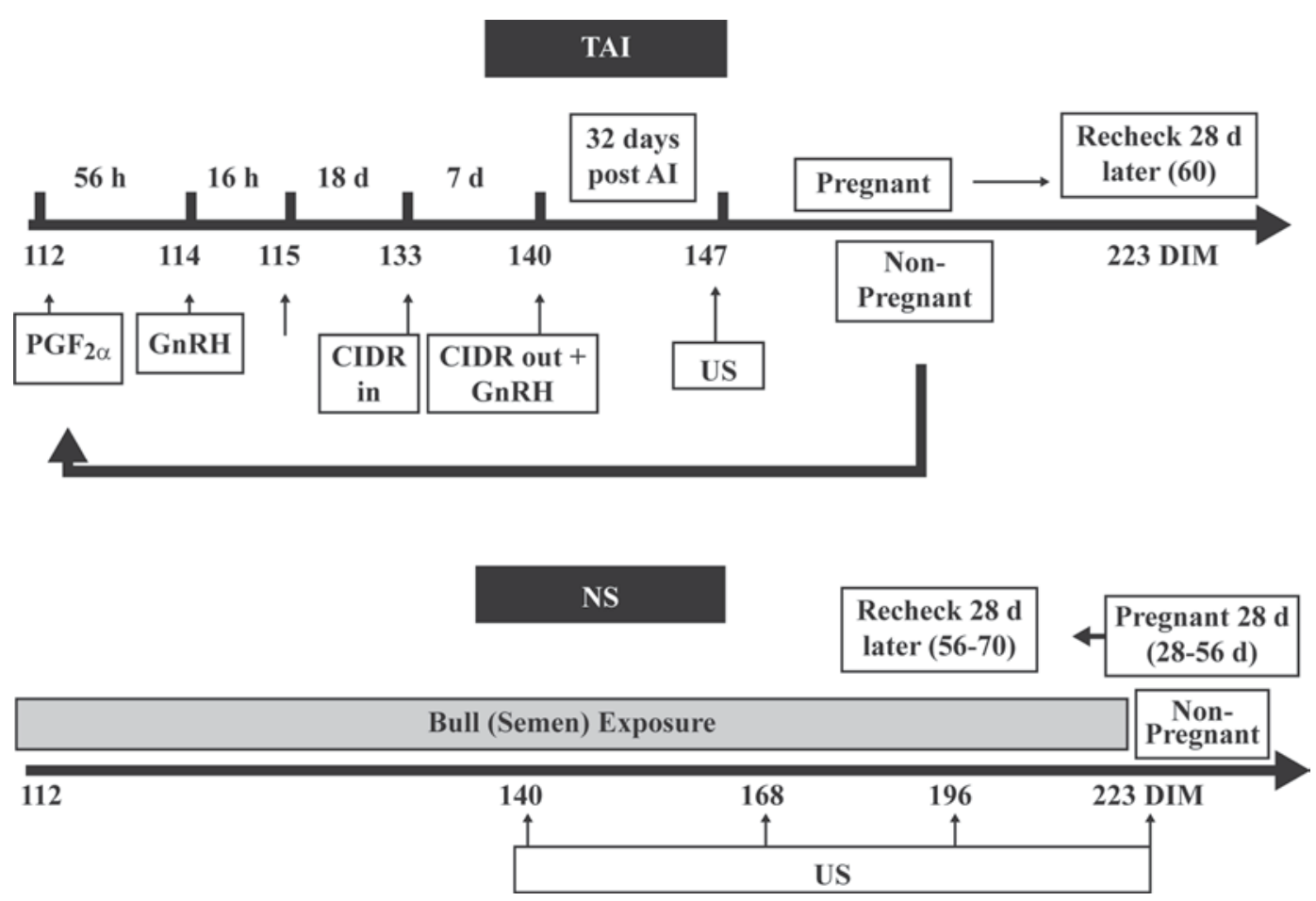

Figure 2. Timeline of reproductive events for nonpregnant cows to the first service and respective services in timed AI (TAI) and natural service (NS) breeding programs. US = ultrasonography examination; CIDR = controlled internal drug-releasing insert.

amniotic vesicle as determined by transrectal palpation (Zemjanis, 1970). Gestation age from 28 to $34 \mathrm{~d}$ was determined by ultrasound and from 35 to $56 \mathrm{~d}$ by ultrasound in combination with transrectal palpation.

Cows diagnosed nonpregnant were reexamined for pregnancy status by ultrasound $28 \mathrm{~d}$ later to detect pregnancy in cows that were less than $28 \mathrm{~d}$ of gestation at the previous ultrasound diagnosis (i.e., 28 to $56 \mathrm{~d}$ pregnant), utilizing the same criteria described above for ultrasound and transrectal palpation. This procedure was similar for subsequent groups assigned weekly to the NS group up to $223 \mathrm{~d}$ postpartum. Cows diagnosed pregnant were reconfirmed $28 \mathrm{~d}$ later to identify pregnancy loss. The bull-to-cow ratio in the NS herds was 1 bull per 20 nonpregnant cows. Day postpartum when pregnancy occurred in NS bred cows was calculated by subtracting the day of pregnancy from the days postpartum when pregnancy was diagnosed. For example, a cow diagnosed pregnant $32 \mathrm{~d}$ at $130 \mathrm{~d}$ postpartum was pregnant at $98 \mathrm{~d}$ postpartum (i.e., 130 to $32 \mathrm{~d}$ ). The interval between services in the TAI group was $35 \mathrm{~d}$ because of the process of carrying out the resynchronization protocol. Therefore, days postpartum when pregnancy occurred to first, second, third, fourth, or fifth service for cows in the TAI group were classified as follows: $\mathrm{d} 80 \pm 3$, first service; d 115 \pm 3 , second service; d $150 \pm 3$, third service; $185 \pm 3$ d, fourth service, and $220 \pm 3$ d, fifth service. For cows in the NS group, when pregnancy was diagnosed from 28 to $56 \mathrm{~d}$, the first, second, third, fourth, fifth, sixth, seventh, or eighth services were classified at d 70 to 90 , d 91 to 111 , d 112 to 132 , d 133 to 153 , d 154 to 174 , d 175 to 195 , d 196 to 216 , and d 217 to 223 postpartum, respectively. A cow in the NS group diagnosed 40-d pregnant at $150 \mathrm{~d}$ postpartum would have conceived at 110 d (i.e., 150 - 40 d) postpartum or at her second service.

\section{Pregnancy Loss}

Because of the reproductive management schemes, NS cows were at different stages of gestation when pregnancy was diagnosed than TAI cows, which were consistently diagnosed pregnant at $32 \mathrm{~d}$. Consequently, stage of gestation when pregnancy was diagnosed in the NS group was categorized by $4 \mathrm{~d}$ intervals ( 28 to 32,33 to 36,37 to 40,41 to 44,45 to 48,49 to 52 , and 53 to $56)$ in an attempt to discern the effect of embryonic age on pregnancy loss.

\section{Bull Management}

Twenty-six bulls 18 mo old at the beginning of the study were used. All bulls underwent a breeding 
soundness evaluation according to the guidelines of the Society for Theriogenology (Chenoweth, 1992) before cow exposure. In addition, bulls were tested for Tritrichomonas fetus using a smegma sample cultured in a modified diamond media (InPouch TF, Biomed Diagnostics, White City, OR). Both of these tests were performed every 3 mo for a total of 5 evaluations for each bull. All bulls were rested for $14 \mathrm{~d}$ after $14 \mathrm{~d}$ of cow exposure. The breeding soundness evaluation included a physical examination, testicular evaluation, measurement of scrotal circumference, and evaluation of sperm morphology and motility following electroejaculation. Only bulls classified as potential satisfactory breeders were used. This classification requires a minimum of $31 \mathrm{~cm}$ for scrotal circumference for bulls between 15 to 18 mo of age, a minimum of individual sperm motility of $30 \%$, and $70 \%$ normal spermatozoa. In addition, the bulls were tested for bovine viral diarrhea by immunohistochemistry of skin using an ear notch sample. All bulls were vaccinated according to farm operational practices for infectious bovine rhinotracheitis, bovine viral diarrhea, parainfluenza 3, bovine respiratory syncytial virus, leptospirosis, clostridial diseases, and campylobacteriosis.

\section{Milk Production Data and BCS}

Milk weights were recorded once a month for 988 cows $(\mathrm{n}=484$ and $\mathrm{n}=504$ for NS and TAI, respectively). First measurements occurred at different days after calving for the first monthly sample depending upon day of parturition and day of the monthly milk test for cow and herd, respectively. Because cows were randomly assigned to the treatments on a weekly basis, the first day postpartum measurement was balanced between groups. Data for the first 3 mo of lactation were obtained from the DHIA (Raleigh, NC). Cows in both the NS and TAI groups underwent a BCS evaluation at $70 \pm 3 \mathrm{~d}$ postpartum before introduction to the bulls in NS or before receiving the GnRH injection in TAI, using a scale of 1 to 5 according to Ferguson et al. (1994).

\section{Temperature Humidity Index}

The temperature $\left({ }^{\circ} \mathrm{F}\right)$ and relative humidity $(\%)$ data were obtained from the Florida Automated Weather Network (http://fawn.ifas.ufl.edu/scripts/reportrequest.asp). The data were collected from January 2007 to March 2008. The weather station is located in Alachua, Florida, approximately 30 miles from the experimental location. Average daily temperaturehumidity index (THI) was calculated as described by West (1993): $\mathrm{THI}=$ temperature $\left({ }^{\circ} \mathrm{F}\right)-[0.55-(0.55 \times$ relative humidity) $] \times($ temperature -58$)$. The THI was the criterion used to determine effect of season (warm or cold) on reproductive performance. The maximum daily THI was categorized as cool when THI $<72$, or warm when THI $\geq 72$. The THI on the day of the first TAI or the first day of exposure to bulls was used in the statistical analysis.

\section{Blood Sampling and Evaluation of Cyclicity}

Blood samples (approximately $6 \mathrm{~mL}$ ) were collected from a subset of 608 cows $(\mathrm{NS}=302$ and TAI $=306)$ before the second $\mathrm{PGF}_{2 \alpha}$ of the presynchronization program and again 9 d later, which corresponded to $56 \pm$ 3 and $65 \pm 3 \mathrm{~d}$ postpartum. Sampling was collected by puncture of the median coccygeal vein or artery using evacuated tubes containing $\mathrm{K}_{2}$ EDTA for plasma separation (Becton Dickinson, Franklin Lakes, NJ). Samples were placed immediately on ice and transported to the laboratory within $5 \mathrm{~h}$ of collection. Blood tubes were centrifuged at $1,500 \times g$ for $15 \mathrm{~min}$, and plasma was frozen at $-25^{\circ} \mathrm{C}$ until analysis. Analysis of progesterone in plasma was determined using a solid phase radioimmunoassay (Coat-A-Count, Progesterone In vitro Diagnostic Test Kit, Diagnostic Products Corp., Los Angeles, CA). Plasma concentrations of progesterone of known values were used in duplicates in every assay to calculate inter- and intraassay coefficients of variation. The known samples were plasma from an ovariectomized cow $(0.7 \mathrm{ng} / \mathrm{mL})$, a low progesterone sample (1.0 $\mathrm{ng} / \mathrm{mL})$, and high progesterone sample $(5.0 \mathrm{ng} / \mathrm{mL}$. The inter- and intraassay CV were 5.74 and $11.1 \%$, respectively. Cows were reported as cyclic if they had progesterone plasma concentration equal to or greater than $1.0 \mathrm{ng} / \mathrm{mL}$ in at least 1 of the 2 samples, or noncyclic if both samples were below $1.0 \mathrm{ng} / \mathrm{mL}$.

\section{Health Disorder Monitoring Program and Treatments}

Farm personnel were trained and farm operational procedures were created by the herd veterinarian (corresponding author) to provide a reliable source for health monitoring and prompt treatment. All cows underwent a postpartum health monitoring program consisting of daily evaluation of rectal temperature and attitude from d 2 to 10 postpartum. Rectal temperature was determined with the use of a digital thermometer (GLA M500HPDT, Agricultural Electronics, San Luis Obispo, CA) between 0700 and 0900 h, after milking. Retained placenta was defined as the presence of fetal membranes $24 \mathrm{~h}$ after calving. Cows that either appeared sick (inappetence, depressed, sunken or tented eyes) or had a rectal temperature $\geq 39.4^{\circ} \mathrm{C}$ were examined for vaginal discharge, urine ketones, displacement 
of abomasum, and respiratory disorder. The criterion for diagnosis of metritis was the presence of a watery, brown, fetid discharge from the vulva (i.e., noted after palpation per rectum of the uterus) with rectal temperature $\geq 39.4^{\circ} \mathrm{C}$. Urine was evaluated for ketonuria using urine test strips (Ketostix, Bayer Diagnostics, Tarrytown, NY). Clinical ketosis was characterized by inappetence, depressed attitude, and presence of ketonuria according to the degree of color change in the test strips. Cows were examined for clinical mastitis by herd personnel during each milking. A case of mastitis was characterized by the presence of abnormal milk or by signs of inflammation in one or more quarters or by both situations. Respiratory disorder was categorized by the presence of abnormal lung sounds, cough, increased respiratory rate, decreased milk production, and fever. Cows were examined for clinical lameness on a weekly basis as they walked out of the milking parlor to barns. Cows affected with lameness exhibited an arched back posture while standing and walking and an abnormal gait. Lame cows were examined on a tilt table for lesions and treatment by a professional hoof trimmer. Morbidity was defined as the occurrence of at least one health disorder in the first $70 \mathrm{~d}$ postpartum.

\section{Statistical Analysis}

The outcomes for comparison of reproductive performance between NS and TAI were the proportion of cows pregnant in the first $21 \mathrm{~d}$ of breeding, 21-d cycle PR, daily rate of pregnancy in the first $223 \mathrm{~d}$ postpartum, median days nonpregnant, and proportion of pregnant cows at $223 \mathrm{~d}$ postpartum. To evaluate the 21-d cycle PR in both NS and TAI cows, an assumption was made that cows were eligible to be bred every 21 $\mathrm{d}$ in both groups, despite the fact that TAI cows had a breeding opportunity only every $35 \mathrm{~d}$. Therefore, a breeding eligibility period was considered every $21 \mathrm{~d}$ up to $223 \mathrm{~d}$ postpartum for both groups.

The proportions of pregnant cows during the first 21 $\mathrm{d}$ of breeding and at the end of $223 \mathrm{~d}$ postpartum were analyzed by logistic regression using PROC LOGISTIC (SAS Institute, 2003). The model included the effects of group (NS vs. TAI), parity (primiparous vs. multiparous), BCS, categorized as $\leq 2.75$ or $>2.75$, season of breeding (warm vs. cool), morbidity, and interactions of group with parity, BCS, season of breeding, and morbidity. Modeling was performed using backward stepwise selection with the significance level of stay when $\alpha \leq 0.10$. The model fit statistics were performed by comparison of the difference in the deviances by the likelihood-ratio statistic test. Adjusted odd ratio and 95\% confidence intervals (CI) were calculated.
The 21-d cycle PR was analyzed using the GLIMMIX procedure for generalized linear mixed models (SAS Institute, 2003). The model included the effects of group, parity, BCS, season of breeding, and morbidity. The rate of pregnancy in the first $223 \mathrm{~d}$ postpartum (daily $\mathrm{PR}$ ) and median days nonpregnant were analyzed using Cox's proportional hazards regression model (PROC PHREG) and the Kaplan Meyer survival curves (PROC LIFETEST; SAS Institute, 2003). The Cox's model included effects of group, parity, BCS categorized, season of breeding, morbidity, and the interactions of group and season of breeding, and group and morbidity. When interactions were nonsignificant $(P>0.10)$, they were dropped from the model. The adjusted hazard ratios (AHR) and the 95\% CI were calculated.

To determine the impact of milk yield in the first 3 mo postpartum on reproductive performance of dairy cows, additional analyses were performed with 988 cows that had milk yield data of the 1,055 cows in the study. The models were the same described above, but included milk yield either as a continuous variable or categorized into quartiles within primiparous and multiparous cows.

Cow days at risk was calculated as the cumulative number of days for cows between exposure to bulls and pregnancy or end of study in the NS group, and between first AI and pregnancy or end of study for the TAI group. The proportion of NS and TAI bred cows affected by health disorders were analyzed by chi-square. Pregnancy loss was analyzed by chi-square analysis (SAS Institute, 2003) and was categorized accordingly with the age of the embryo at the time pregnancy was diagnosed.

Differences with $P \leq 0.05$ were considered significant, and those with $0.05<P<0.10$ were considered a tendency.

\section{RESULTS}

\section{Assessment of Bulls}

Six bulls $(23.1 \%$; 6/26) were culled during the study: 2 became lame, 1 developed a bad temperament, 1 had a positive test for $T$. fetus, and 2 were classified as unsatisfactory potential breeders at the completion of the breeding soundness evaluation.

\section{Reproductive Performance}

The proportion of pregnant cows in the first $21 \mathrm{~d}$ of breeding did not differ $(P=0.17)$ between groups (Table 1 ). The overall 21-d cycle PR, which included 8 and 5 service opportunities for NS and TAI, respective- 
Table 1. Pregnancy rates calculated for every 21-d cycle for cows bred by natural service (NS) or timed AI (TAI) throughout the study

\begin{tabular}{llc}
\hline & \multicolumn{2}{c}{ Treatment, \% (no./no.) } \\
\cline { 2 - 3 } Item & \multicolumn{1}{c}{$\mathrm{NS}$} & TAI \\
\hline 21 -d cycle number & & \\
1 & $34.2(175 / 512)$ & $37.4(203 / 543)$ \\
2 & $24.3(82 / 337)$ & $28.7(97 / 338)$ \\
3 & $13.9(35 / 251)$ & $0.0(0 / 241)$ \\
4 & $26.8(56 / 209)$ & $28.9(63 / 218)$ \\
5 & $31.1(47 / 151)$ & $27.0(38 / 141)$ \\
6 & $15.8(16 / 101)$ & $0.0(0 / 97)$ \\
7 & $11.8(10 / 80)$ & $14.4(14 / 97)$ \\
8 & $19.4(13 / 67)$ & $\overline{-}$ \\
Total $^{2}$ & $25.7(421 / 1,641)$ & $25.0(417 / 1,669)$ \\
\hline
\end{tabular}

${ }^{1}$ To evaluate the 21-d cycle pregnancy rate in both NS and TAI cows, an assumption was made that cows were eligible to be bred every $21 \mathrm{~d}$ despite the fact that TAI cows had a breeding opportunity only every $35 \mathrm{~d}$.

${ }^{2}$ Data from the eighth 21 -d cycle were not included in the analysis.

ly, was not different between groups (25.7 and $25.0 \%$ for NS and TAI, respectively). However, the rate of pregnancy differed $(P=0.05)$ between groups and was $15 \%$ greater $(\mathrm{AHR}=1.15 ; 95 \% \mathrm{CI}=1.00$ to 1.31$)$ for NS than TAI (Figure 3). The median and mean days to pregnancy for NS-bred cows were $111 \mathrm{~d}(95 \% \mathrm{CI}=$ 105 to 126 ) and $131.5 \pm 2.3 \mathrm{~d}$, respectively, and for TAI cows were $116 \mathrm{~d}(95 \% \mathrm{CI}=115$ to 118$)$ and $137.9 \pm 2.9$ $\mathrm{d}$, respectively. The survival curves did not differ until $150 \mathrm{~d}$ postpartum, when they began to separate. To reinforce this observation, an additional survival analysis was performed for the interval to pregnancy up to 150 d postpartum, in which time nonpregnant cows were censored. In the latter scenario, group did not influence $(P=0.44)$ the rate of pregnancy $(\mathrm{AHR}=1.06 ; 95 \%$ $\mathrm{CI}=0.91$ to 1.23$)$. Nevertheless, at $223 \mathrm{~d}$ postpartum, which was the endpoint of the study, the proportion of pregnant cows was greater $(P=0.001)$ for NS than for TAI $(\mathrm{NS}=84.8 \%$ and $\mathrm{TAI}=76.4 \%)$. Cow days at risk for pregnancy were not different between NS and TAI (30,978 and 29,424 d, respectively).

\section{Parity, BCS, and Milk Production}

Parity did not $(P=0.15)$ affect the proportion of cows pregnant in the first $21 \mathrm{~d}$ of breeding. However, a greater proportion $(P<0.001)$ of primiparous cows was pregnant at the end of $223 \mathrm{~d}$ of breeding than multiparous cows (87.7 vs. $77.8 \%$ ) because primiparous cows had a $27 \%$ greater $(P=0.002)$ daily PR than multiparous cows $(\mathrm{AHR}=1.27 ; 95 \% \mathrm{CI}=1.09$ to 1.48$)$.

At $70 \pm 3$ d postpartum, the distribution among BCS categories was not different $(P=0.66)$ between TAI

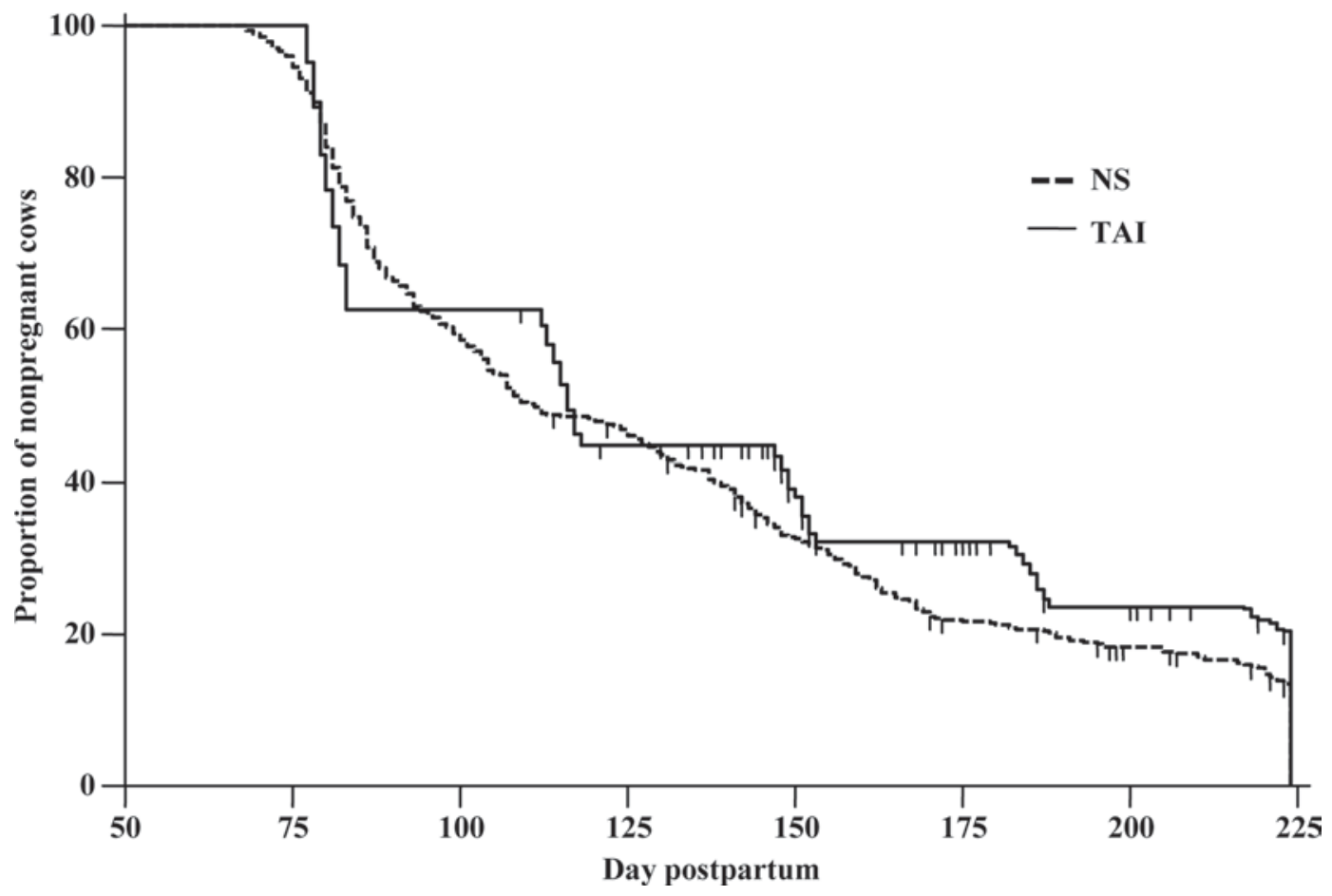

Figure 3. Survival curves for proportion of nonpregnant cows by days postpartum for cows bred by natural service (NS) or timed AI (TAI) in the first $223 \mathrm{~d}$ postpartum. Median interval to pregnancy for NS and TAI groups was $111 \mathrm{~d}(95 \%$ confidence interval $[\mathrm{CI}]=104$ to 125$)$ and $116 \mathrm{~d}(95 \% \mathrm{CI}=115$ to 117$)$, respectively. The rate of pregnancy in the $223 \mathrm{~d}$ postpartum was greater $(P=0.05)$ for NS than TAI (adjusted hazard ratio $=1.15 ; 95 \% \mathrm{CI}=1.00$ to 1.31$)$. 
Table 2. Effect of health disorders on proportion of pregnant cows in the first $21 \mathrm{~d}$ of breeding for cows bred by natural service or by timed AI

\begin{tabular}{lccc}
\hline & \multicolumn{2}{c}{ Disease, \% (no./no.) } & \\
\cline { 2 - 3 } Type of disease & \multicolumn{1}{c}{ Yes } & No & $P$-value \\
\hline Metritis $^{1}$ & $31.5(28 / 89)$ & $35.7(345 / 966)$ & 0.49 \\
Lameness & $25.6(11 / 43)$ & $35.8(362 / 1,012)$ & 0.19 \\
Retained placenta & $28.5(15 / 52)$ & $35.7(358 / 1,003)$ & 0.37 \\
Respiratory & $17.2(5 / 29)$ & $35.9(368 / 1,026)$ & $<0.05$ \\
Mastitis & $22.7(20 / 88)$ & $36.5(353 / 967)$ & $<0.01$ \\
Ketosis & $15.4(6 / 39)$ & $36.1(367 / 1,016)$ & $<0.01$ \\
Morbidity & $26.4(76 / 288)$ & $38.7(297 / 767)$ & $<0.01$ \\
\hline
\end{tabular}

${ }^{1}$ Variable not distributed equally between natural service and timed AI.

and NS: BCS $\leq 2.75$ were $52.5 \%$ for NS and $53.9 \%$ for TAI; BCS $>2.75$ were $47.5 \%$ for NS and $46.1 \%$ for TAI. Cows with BCS greater than 2.75 had increased $(P=$ $0.004)$ proportion of pregnant cows in the first $21 \mathrm{~d}$ of breeding (39.9 vs. $32.4 \%$; adjusted odds ratio $=1.46$; $95 \% \mathrm{CI}=1.26$ to 1.89$)$ and had an increased $(P=$ $0.02)$ daily $\mathrm{PR}$ in the first $223 \mathrm{DIM}(\mathrm{AHR}=1.18 ; 95 \%$ $\mathrm{CI}=1.03$ to 1.35$)$. Despite those effects, no effect $(P$ $=0.33$ ) of BCS was observed for the overall cumulative proportions of pregnant cows at the end of the study, which were $78.6 \%$ for cows with BCS $\leq 2.75$ and $82.4 \%$ for cows $>2.75$.

When additional analyses were performed with the subset of 988 cows with milk production data, the daily rate of pregnancy tended $(P=0.08)$ to increase with a concurrent increase in milk yield $(\mathrm{AHR}=1.01 ; 95 \% \mathrm{CI}$ $=1.00$ to 1.01). At the end of 223 DIM, the proportion of pregnant cows was not $(P=0.23)$ affected by milk production in the first 3 mo of lactation.

\section{Cyclic Status, Seasonality, and Health Disorders}

Progesterone analyses indicated that 83.1\% (251/302) of cows in the NS group and $87.2 \%(267 / 306)$ of cows in the TAI group were cyclic (progesterone $>1 \mathrm{ng} / \mathrm{mL}$ in at least 1 sample) before exposure to NS or onset of the TAI protocol. The percentages of cyclic cows were not different $(P=0.17)$ between groups, and cyclic status did not affect $(P=0.53)$ the proportions of pregnant cows in the first $21 \mathrm{~d}$ of breeding, which were $35.4 \%$ and $38.6 \%$ for noncyclic and cyclic cows respectively.

Cows receiving their first breeding during the cool season had increased $(P<0.01)$ pregnancy in the first $21 \mathrm{~d}$ of breeding (41.2 vs. $27.7 \%)$, 21-d cycle PR (27.5 vs. $22.5 \%)$, and daily $\mathrm{PR}(\mathrm{AHR}=1.22 ; 95 \% \mathrm{CI}=1.06$ to 1.41). It is important to indicate that no interaction between treatment and heat stress was observed for the proportion of cows pregnant in the first $21 \mathrm{~d}$ of breeding or PR.
The only health disorder that was not $(P=0.03)$ distributed equally between TAI and NS was metritis $(\mathrm{TAI}=6.6 \%$ and $\mathrm{NS}=10.3 \%)$. However, metritis did not affect the proportion of pregnant cows in the first $21 \mathrm{~d}$ of breeding (Table 2). On the other hand, the proportion of pregnant cows in the first $21 \mathrm{~d}$ of breeding was less in cows with mastitis $(P<0.01)$, respiratory disorder $(P<0.05)$, ketosis $(P<0.01)$, and morbidity $(P<0.01)$. Morbidity influenced $(P=0.002)$ the rate of pregnancy and healthy cows had a $28 \%$ greater daily PR than cows affected by at least one health problem $(\mathrm{AHR}=1.28 ; 95 \% \mathrm{CI}=1.09$ to 1.49$)$.

\section{Pregnancy Loss}

The overall pregnancy loss considering the gestation period from d 28 to 56 in the NS group and $32 \mathrm{~d}$ for TAI was lower $(P=0.02)$ for NS than TAI-bred cows (10.4\% and $15.2 \%, P<0.05$; respectively; Table 3 ). However, pregnancy loss in the NS group for cows diagnosed pregnant between 28 to $32 \mathrm{~d}$ of gestation was the same as for TAI cows at $32 \mathrm{~d}$ of gestation $(14.9 \%$ and $15.2 \%$, respectively), as shown in Table 3 .

\section{DISCUSSION}

Following the recommendations of the Society for Theriogenology (Chenoweth, 1992) for breeding soundness, a culling rate of $23.1 \%$ occurred in bulls used in this study. Kastelic et al. (2000) reported that 20 to $40 \%$ of bulls from an unselected population might have reduced fertility. Because these bulls were classified as potential satisfactory breeders before cow exposure and were removed from the study and replaced with sound bulls, the potential for using subfertile bulls in the NS group was minimized. Despite the fact that bulls used in this study had repeatedly breeding soundness evaluations (every $3 \mathrm{mo}$ for a total of 5 evaluations), which is more than what is commonly done, our culling 
rates were not greater than what is expected for service bulls in a random population (Kastelic et al., 2000). Our approach to bull evaluation and management was chosen to assure that subfertile bulls could be identified rapidly and removed from the herd to avoid a negative effect on reproduction.

The overall 21-d cycle PR in the NS group of $25.7 \%$ was substantially greater than previously reported by de Vries et al. (2005) in NS herds in the states of Florida and Georgia where 21-d cycle PR was $14.0 \%$. Our results can be attributed to the stringent bull management program employed (periodic resting and breeding soundness evaluation) and early removal of unsound bulls, which reduced the potential for deviation in bull fertility during cow exposure. Cows in the TAI group had a first 21-d cycle PR of $37.4 \%$, similar to a PR to first TAI of $37 \%$ and $37.9 \%$, reported by Pursley et al. (1997a) and Santos et al. (2009), respectively. The greater proportion of pregnant cows observed in the NS group at the end of the study is attributed to differences in breeding dynamics between groups. In the NS group, bulls had the potential for daily detection of estrus and breeding of nonpregnant cows. On the other hand, because of the TAI resynchronization scheme, nonpregnant cows in this group required $35 \mathrm{~d}$ to be reinseminated, and thus the number of days to become pregnant increased. However, within this scenario, up to $223 \mathrm{~d}$ postpartum cows in the TAI group had only 5 opportunities to be bred compared with a potential 8 times for cows in the NS group. The increased median number of days to pregnancy observed for TAI cows can also be attributed to this difference in breeding opportunities. A greater number of nonpregnant cows in the NS group had earlier opportunities to be bred than TAI cows under the same 21-d cycle PR; consequently the final outcome for median time to pregnancy favored the NS group.

A greater proportion of pregnant cows and daily PR at $223 \mathrm{~d}$ postpartum was observed for primiparous than multiparous cows This finding indicates that primiparous cows are more fertile than multiparous cows, which agrees with the study of Santos et al. (2009) that reported a greater PR to first service in primiparous cows. In the present study, a greater proportion of pregnant cows in the first $21 \mathrm{~d}$ of breeding was found for cows with a BCS $>2.75$ at $70 \mathrm{~d}$ postpartum. This is in agreement with the reports by Santos et al. (2009) and Moreira et al. (2000) in which BCS around $70 \mathrm{~d}$ postpartum positively influenced PR. Results from the present study support the concept that BCS at $70 \mathrm{~d}$ postpartum is of paramount importance for the establishment and maintenance of pregnancy in highproducing dairy cows.
Table 3. Pregnancy losses according to age of gestation at the initial pregnancy diagnosis in cows bred by natural service (NS) or timed artificial insemination (TAI)

\begin{tabular}{llc}
\hline Treatment & $\begin{array}{l}\text { Age of pregnancy } \\
\text { at first diagnosis (d) }\end{array}$ & $\begin{array}{c}\text { Pregnancy loss, } \\
\% \text { (no./no.) }\end{array}$ \\
\hline TAI & 32 & $15.2(63 / 415)^{\mathrm{a}}$ \\
NS & 28 to 56 & $10.4(45 / 434)^{\mathrm{b}}$ \\
NS 1 & 28 to 32 & $14.9(18 / 121)$ \\
NS 2 & 33 to 36 & $11.6(11 / 95)$ \\
NS 3 & 37 to 40 & $14.9(10 / 67)$ \\
NS 4 & 41 to 44 & $5.3(2 / 38)$ \\
NS 5 & 45 to 48 & $5.7(3 / 53)$ \\
NS 6 & 49 to 52 & $0(0 / 11)$ \\
NS 7 & $>52$ & $2.0(1 / 49)$ \\
TAI and NS total & 28 to 56 & $12.7(108 / 849)$ \\
\hline
\end{tabular}

${ }^{a, b}$ Means within same column with different superscripts differ $(P<$ $0.05)$.

Cyclicity did not affect the proportion of pregnant cows in the first $21 \mathrm{~d}$ of breeding in the current study. In contrast, Santos et al. (2009) reported a greater PR $58 \mathrm{~d}$ post AI to first service in cyclic compared with noncyclic cows. However, in our study the percentage of cyclic cows was greater than expected, which diminished sample size for a valid comparison between cyclic and noncyclic cows and likely limited the power to identify an effect of cyclicity in this study. A bull effect inducing noncyclic animals to ovulate also may have occurred in cows bred by NS. These factors may have contributed to our inability to detect a difference in the proportion of pregnant cows in the first $21 \mathrm{~d}$ of breeding between cyclic and noncyclic cows.

Cows bred during the warm season had a lower proportion of pregnant cows in the first $21 \mathrm{~d}$ of breeding in both NS and TAI bred cows. This agrees with a previous report (de Vries et al., 2005) that showed conception rates of lactating cows located in Florida decrease to $20 \%$ during summer months (June through August). Furthermore, in the present study PR continued to be low during fall (September and October) when THI decreased. During periods of heat stress (summer), overall PR dropped for cows bred by either AI or NS, but no difference in PR was found between groups. In contrast, de Vries et al. (2005) reported that during summer, cows bred by NS had greater 21-d cycle PR than cows bred by AI. However, in the de Vries et al. (2005) study, 21-d cycle PR included all cows eligible for AI during summer. The fact that some dairy producers in Florida choose not to breed cows during summer may have biased the estimates reported by de Vries et al. (2005). During hot weather, some reduction of bull fertility may be expected because of lowered semen quality associated with an increase in abnormal heads, abnormal acrosome, proximal droplets, and a corresponding decrease in motility (Ott, 1986). In our 
study, bulls were housed and managed using heat stress abatement conditions designed for lactating dairy cows (shade, fans, evaporative cooling), and changes in bull semen quality may not have occurred or were less severe. Therefore, the depression in PR observed during summer in this study with NS and TAI could be attributed to the effect of heat stress on cow fertility.

The study herd employed a postpartum health monitoring program with the aim to treat disorders promptly. Among the health disorders evaluated, metritis did not affect PR to first service. This result supports the finding by Benzaquen et al. (2007) who reported that cows with metritis did not have impaired fertility. Our finding and those of Benzaquen et al. (2007) reinforced the concept that a postpartum health monitoring program, which allows for early diagnosis and treatment of metritis, may mitigate impairment in fertility related to metritis. On the other hand, the proportion of pregnant cows in the first $21 \mathrm{~d}$ of breeding was less in cows with mastitis, respiratory disorder, ketosis, and morbidity.

The greater pregnancy loss observed in TAI-bred cows in our study can be attributed to the earlier time of gestation when pregnancy was diagnosed in this group. In a report by Santos et al. (2004), late pregnancy losses were characterized by corpus luteum maintenance to the end of the differentiation stage, at approximately $42 \mathrm{~d}$ of gestation, and were more frequent than pregnancy losses after this stage. This pattern of pregnancy loss agrees with our lower pregnancy losses after $40 \mathrm{~d}$ of gestation. Therefore, we attribute the greater pregnancy loss observed in TAI compared with NS bred cows to the days of gestation when diagnosis of pregnancy occurred. Indeed, pregnancy loss was the same when compared at comparable stages of pregnancy in the present study.

The final logistic regression model revealed that the variables affecting the proportion of pregnant cows in the first $21 \mathrm{~d}$ of breeding were BCS and an interaction between seasonality and morbidity. The effect of BCS on fertility in dairy cows has been well documented previously and possible reasons are clearly described (Domecq et al., 1997; López-Gatius et al., 2002; Santos et al., 2009).

\section{CONCLUSIONS}

The TAI breeding program did not result in a greater 21-d cycle PR compared with NS as initially hypothesized. A greater proportion of pregnant cows at the end of the study occurred in NS-bred cows because they had more opportunities for breeding to occur compared with the TAI reproductive management program. When reproductive performance was compared with the same breeding eligibility period of 21-d cycle PR, there was no difference between NS and TAI. In conclusion, NS and TAI are 2 breeding systems that can be used strategically to minimize problems related to detection of estrus, but the extended interinsemination interval in TAI reduces daily PR because these cows have fewer opportunities for breeding. Whether or not TAI is more economical than NS warrants investigation.

\section{ACKNOWLEDGMENTS}

Authors express their appreciation to Dairy Production Systems of Florida and their staff for allowing access to their animals and facilities and for assistance during the study. The authors thank Pfizer Animal Health (New York, NY), Intervet Inc. (Millsboro, DE), Select Sires Power (Tunkhannock, PA), and the Southeast Milk Check-Off Education and Research Program (Gainesville, FL) for their financial support.

\section{REFERENCES}

Benzaquen, M. E., C. A. Risco, L. F. Archbald, P. Melendez, M. J Thatcher, and W. W. Thatcher. 2007. Rectal temperature, calvingrelated factors, and the incidence of puerperal metritis in post partum dairy cows. J. Dairy Sci. 90:2804-2814.

Caraviello, D. Z., K. A. Weigel, P. M. Fricke, M. C. Wiltbank, M. J. Florent, N. B. Cook, K. V. Nordlund, N. R. Zward, and C. L. Rawson. 2006. Survey of management practices on reproductive performance of dairy cattle on large US commercial farms. J. Dairy Sci. 89:4723-4735.

Cartmill, J. A., S. Z. El-Zarkouny, B. A. Hensley, T. G. Rozell, J. F. Smith, and J. S. Stevenson. 2001. An alternative AI breeding protocol for dairy cows exposed to elevated ambient temperatures before or after calving or both. J. Dairy Sci. 84:799-806.

Champagne, J. D., J. H. Kirk, and J. P. Reynolds. 2002. Bull management practices on California dairies: Implications for education and veterinary services. Pp. 15-21 in Proc. 15th Annu. Fall Symp., Univ. of California-Davis, Davis, CA.

Chenoweth, P. J. 1992. A new bull breeding soundness evaluation form. Pp. 63-70 in Proc. Annu. Meeting, Society for Theriogenology, San Antonio, TX.

de Vries, A., C. Steenholdt, and C. A. Risco. 2005. Pregnancy rates and milk production in natural service and artificially inseminated dairy herds in Florida and Georgia. J. Dairy Sci. 88:948-956.

Domecq, J. J., A. L. Skidimore, J. W. Lloyd, and J. B. Kaneene. 1997. Relationship between body condition scores and conception at first service at first artificial insemination in a large dairy herd of high yielding Holstein cows. J. Dairy Sci. 80:113-120.

Ferguson, J. D., D. T. Galligan, and N. Thomsen. 1994. Principal descriptors of body condition score in Holstein dairy cattle. J. Dairy Sci. 77:2695-2703.

Ginther, O. J. 1998. Ultrasonic Imaging and Animal Reproduction: Cattle. Book 3. Equiservices Publishing, Cross Plains, WI.

Kastelic, J. P., R. B. Cook, and G. H. Coutler. 2000. Scrotal/testicular thermoregulation in bulls. In Topics in Bull Fertility. P. J. Chenoweth, ed. Int. Veterinary Information Service, Ithaca, NY

López-Gatius, F., P. Santolaria, J. Yániz, J. Rutland, and M. LópezBéjar. 2002. Factors affecting pregnancy loss from gestation d 38-90 in lactating dairy cows from a single herd. Theriogenology 57:1251-1261.

Moreira, F., C. Risco, M. F. A. Pires, J. D. Ambrose, M. Drost, M. DeLorenzo, and W. W. Thatcher. 2000. Effect of body condition on reproductive efficiency of lactating dairy cows receiving a timed insemination. Theriogenology 53:1305-1319. 
NAHMS. 2002. Part 1: Reference of dairy health and management in the United States. Center for Epidemiol. Anim. Health, National Animal Health Monitoring System, Fort Collins, CO.

Niles, D., C. A. Risco, and M. J. Thatcher. 2002. Seasonal evaluation of artificial insemination and natural service pregnancy rates in dairy herds. Compend. Contin. Educ. Pract. Vet. 24:44-48.

NRC. 2001. Nutrient Requirements of Dairy Cattle. 7th rev. ed., Natl. Acad. Sci. Washington, DC.

Ott, R. S. 1986. Breeding soundness evaluation in bulls. Pages 125-136 in Current Therapy of Theriogenology. 2nd ed., W.B. Saunders Co, Philadelphia, PA.

Overton, M. W., and W. M. Sischo. 2005. Comparison of reproductive performance by artificial insemination versus natural service sires in California dairies. Theriogenology 64:603-613.

Pursley, J. R., M. R. Kosorok, and M. C. Wiltbank. 1997a. Reproductive management of lactating dairy cows using synchronization of ovulation. J. Dairy Sci. 80:301-306.

Pursley, J. R., M. O. Mee, and M. C. Wiltbank. 1995. Synchronization of ovulation in dairy cows using $\mathrm{PGF}_{2 \alpha}$ and $\mathrm{GnRH}$. Theriogenology 44:915-923.

Pursley, J. R., M. C. Wiltbank, J. S. Stevenson, J. S. Ottobre, H. A. Garverick, and L. L. Anderson. 1997b. Pregnancy rates per artificial insemination for cows and heifers inseminated at a synchronized ovulation or synchronized estrus. J. Dairy Sci. 80:295-300.
Santos, J. E. P., H. M. Rutigliano, and M. F. Sá Filho. 2009. Risk factors for resumption of postpartum cyclicity and embryonic survival in lactating dairy cows. Anim. Reprod. Sci. 110:207221.

Santos, J. E. P., W. W. Thatcher, R. C. Chebel, R. L. A. Cerri, and K. N. Galvão. 2004. The effect of embryonic death rates in cattle on the efficacy of estrous synchronization programs. Anim. Reprod. Sci. 82-83:513-535.

SAS Institute. 2003. SAS/STAT Software for Windows 9.1. SAS Institute Inc., Cary, NC, USA.

Smith, J. W., L. O. Ely, W. D. Gilson, and W. M. Groves. 2004 Effects of artificial insemination vs natural service breeding on production and reproduction parameters in dairy herds. Prof. Anim. Sci. 20:185-190.

West, J. W. 1993. Interaction of energy and bovine somatotropin with heat stress. J. Dairy Sci. 77:2091-2102.

Williamson, N., B., R. S. Morris, and G. A. Anderson. 1978. Pregnancy rates and non return rates following artificial and natural breeding in dairy herds. Aust. Vet. J. 54:111-120.

Zemjanis, R. 1970. Diagnostic and Therapeutic Techniques in Animal Reproduction. Williams and Wilkins Co., Baltimore, MD. 